\title{
The Informalization of the Chinese Labor Market
}

\author{
Albert Park \\ Department of Economics \\ University of Michigan \\ Fang Cai \\ Institute of Population and Labor Economics \\ Chinese Academy of Social Sciences
}

This version: August 2009

First version: April 2007

\begin{abstract}
Drawing upon multiple data sources, we document a rapid, unprecedented rise in informal employment in urban China since the mid-1990s. By 2005, 10 percent of urban workers were registered as self-employed, and another 36 percent were undocumented, neither reported by employers nor self-registered. We provide evidence that many of these "missing" workers were likely to be employed in the private sector and in the service sector. Most migrant workers are employed informally, but a significant number of urban permanent residents are also employed informally. Increasing informal employment expands work opportunities but creates challenges for the provision of social insurance and worker protections.
\end{abstract}




\section{The Informalization of the Chinese Labor Market}

\section{The puzzle of China's “missing” workers}

Beginning in the late 1990s, China's urban labor market experienced a rapid diversification of ownership types. The most striking change was the rapid decline of the state and collective sectors. According to official employment statistics published in the China Statistical Yearbooks, employment in the SOE sector, which had actually grown in absolute number from 1990 to 1994, fell at a mean annual rate of 6.4 percent from 1995 to 2000, a total loss of 31.5 million jobs or 15 percent of the urban labor force. The collective sector, which had begun declining earlier, had already shed over 10 percent of the 1990 workforce by 1995, and shrank by 13.8 percent per year from 1995 to 2000, losing 16.5 million jobs over the period. As a share of all urban employment, employment in the state and collective sector fell from 76 percent in 1995 to 41 percent in 2000 to only 27 percent in 2005 (Figure 1 and Table 1). The employment shares of other enterprise ownership forms, especially the private sector and limited liability corporations, increased significantly.

Remarkably, the category of workers that witnessed the fastest rate of increase was "other” workers (see Figure 1 and Table 1). Starting from a low base in 1995, “other” workers increased by 24 percent per year and accounted for 39 percent of all workers in 2002 and 2003, before declining to 36 percent in 2005. These workers can be described as missing workers, because they reflect differences in the numbers of workers reported through different statistical reporting systems. Total urban employment comes from the annual labor force surveys conducted by the National Bureau of Statistics which are sample surveys of the entire population. The number of workers employed by 
different ownership types comes from the Comprehensive Labor Statistics Reporting System (CLSRS), based on direct reporting by all independent accounting units to the National Statistical Bureau each year. Estimates of self-employed workers are based on the number of such individuals registered with the Industrial and Commercial Bureau. The difference between the larger number calculated from the labor force surveys and the smaller number of workers reported by the CLSRS is precisely the "other" category reported in Table 1. In principle, this category should include unreported urban workers and unregistered informal employment, including undocumented work by migrants in urban areas. The large increase in the number of such workers thus suggests that informal urban employment may have increased significantly in recent years.

China's annual population and labor force surveys also are likely to undercount migrants working in urban areas. According to the 2000 census, which did a better job counting long-term migrants, 10.8 percent of the Chinese population did not have a resident permit for the location in which they reside. This compares to just 4.8 percent of the population estimated to be long-term migrants in 1999 and 7.7 percent in 2003 based on the annual population change surveys, which use the same sampling system as the labor force surveys (see China Statistical Yearbook, various years). To the extent that migrants are under-counted in estimates of the total work force and are likely to work in the informal sector, our estimates of informal employment are likely to be underestimates of actual informal employment.

But what is the precise definition of "informal"? The ILO emphasizes that informal employment is characterized by a lack of stability or security. Such employment is often temporary, lacks a formal contract, and does not provide social 
insurance benefits or other worker protections. To some extent, the very fact that workers are not registered by their employers itself is prima facia evidence that such work is informal, because it means that the workers lack formal contracts and there is little if any monitoring of how such workers are treated by their employers (e.g., job termination, social insurance, and working conditions). If "missing” workers and selfemployed workers are counted as informal workers, the share of the urban workforce that was employed informally reached 46 percent in 2005.

The rise of informal employment represents a fundamental change in China's labor market which brings new policy challenges, yet to date the phenomena has received remarkably scant attention. In this paper, we examine multiple sources of evidence to quantify and characterize the extent of informal employment in urban China. We then discuss its potential policy implications.

The increase in “missing” workers just described raises two immediate questions. First, why aren't these workers being reported by their employers? Second, who are these workers and what kind of work are they performing? If economic activity can be hidden from authorities, then taxes can be avoided. This is especially true for the selfemployed or for small, private enterprises. However, even for large, registered work units, there may be strong incentives to avoid signing labor contracts with workers and not reporting such employees. First, by hiring informally, enterprises can avoid having to pay required payroll taxes for pensions, unemployment insurance, medical insurance, and work injuries, which can be quite costly. For example, in Shanghai in 2004, the regular employer contribution rate for these types of insurance totaled 36.5 percent of wages. ${ }^{1}$

\footnotetext{
${ }^{1}$ According to Maitra et al. (2005), base employer contribution rates as a share of wages were 22 percent for pension insurance, 12 percent for medical insurance, 2 percent for unemployment insurance, and 0.5 percent for maternity and
} 
Hiring workers on an informal basis also gives employers greater flexibility to adjust the size of the labor force to respond to changes in economic conditions.

Who are the "missing" workers? We offer four complementary explanations for what types of individuals "missing" workers may include. First, many missing workers may be working in the rapidly growing but very imperfectly monitored private sector, including unregistered self-employed workers. Second, many of the missing workers could be rural migrant workers, who are often hired on an informal basis or are selfemployed and anxious to evade taxes. Third, re-employed laid off workers or retired workers are likely to be hired on an informal, temporary basis, even if they are hired by government departments or state-owned enterprises. Fourth, China's recent adjustments to its GDP statistics suggest that many of the missing workers may work in the tertiary sector, where economic output has been significantly underestimated.

\section{The size of the private sector}

One reason for the confusion about who employs missing workers is that little summary information on employer characteristics is made available from the labor force surveys. If the labor force surveys contained more detailed information about employers and NBS released the tabulated results, then the nature of underreporting might be clearer. Starting in 2001, the China Labor Statistical Yearbooks did begin reporting limited information on the share of labor engaged in different types of employment (Table 2). In 2004, 40 percent of urban laborers worked in "urban units,” which appears to include all categories of workers reported in Table 1 except for private enterprises,

industrial injury insurance. For migrants, the total employer contribution rate is 12.5 percent. Even though many enterprises do not fully comply with contribution requirements even for registered workers, they are subject to audits and fines as well as informal sanctions by government officials. 
self-employed, and other. Multiplying this share by the total number of urban workers (265 million) yields an estimate of 106 million workers in urban units. This turns out to be relatively close to the 111 million number for "unit employment" based on the CLSRS.

What is interesting about Table 2 is that in contrast to Table 1 where 38 percent of workers are "missing," it accounts for nearly all labor not working in urban units. Nearly all of these individuals turn out to be working in the private sector! In 2004, 3.7 percent of urban workers worked in TVEs, 14.0 percent in agriculture, 18.8 percent were private sector employees, 7.1 percent were private employers, and 13.4 percent were selfemployed. Only 2.9 percent are described as “other”. By 2004, nearly all TVEs had been privatized. If one categorizes agriculture as a type of self-employment, then 53 percent of employment was in the private sector, which is much higher than the 21 percent of workers in the private sector or self-employed categories reported in Table $1 .^{2}$ Some categories of urban workers captured in the labor force survey appear to be missed completely by the CLSRS. For instance, TVEs and agriculture, which accounted for 17.7 percent of urban workers in 2004, do not even seem like urban employment categories, but in fact many suburban urban districts do have substantial populations with rural residence permits (hukou). However, even if these two rural categories are excluded, according to Table 2 the private sector would still account for 48 percent of employment. If one subtracts the 11 percent of workers reported to be working in private enterprises by the CLSRS in 2004, who are presumably formally employed, then 37 to 42 percent of the labor force worked informally in the private sector.

\footnotetext{
${ }^{2}$ This could be an underestimate of the size of the private sector, given that it excludes employment in wholly foreignowned firms or in mixed ownership forms with majority private ownership (including TVEs).
} 


\section{Migrant workers}

To get a better sense of the extent to which unreported migrant workers might explain the large "other" category, we use the 2000 census data to examine the correlation between the share of unreported workers and the share of migrant workers in different sectors (Table 2). The census data documents all individuals living in their current place of residence for at least six months in the past year and provides information on the type and place of each individual's residence permit (hukou), as well as each person's occupation and sector of employment (but not ownership type). The first column of Table 2 presents estimates of urban total employment and its distribution among sectors based on the CLSRS, the second column contains corresponding figures from the $0.9 \%$ sample of the 2000 census long form, which is consistent with the labor force surveys in terms of definition, and shows 18.8 percent more employment than that reported by the CLSRS. The last column is the proportion of migrant workers in different sectors based on the census data. Migrants account for 17.1 percent of all workers.

Although the overall share of migrants is similar to the overall share of "missing" workers, this does not necessarily mean that most of the "missing" workers are migrants if, for instance, employers are reporting migrants in the CLSRS but not reporting urban residents. However, the correlation between missing and migrant shares across sectors is about 0.5, suggesting that unreported migrants account for at least some of the missing workers, or that migrants and urban unreported workers are concentrated in the same informal sectors. 
Recently, the China Labor Statistical Yearbook began providing statistics on the number of rural workers, presumably primarily rural migrants, reported by urban units. ${ }^{3}$ In 2004, rural workers accounted for 11.9 percent of workers reported by urban units (6.4 percent of all workers), an increase from 10.4 percent in 2003. The share was smallest in state-owned units (4.5 percent) and larger in collective and other ownership units (17.8 and 24.6 percent). It is likely to be still larger in the private sector. These data do suggest that some migrants are, in fact, being reported by their employers, but that most migrants are undocumented or "missing." As noted earlier, it is also likely that the annual labor force surveys undercount migrants in their total employment estimates.

\section{Informal employment of urban permanent residents}

Another source of information on the ownership types of employers is the urban household survey data collected annually by NBS. Table 4 presents the employment shares for state (including government), collective, and non-public enterprises for the years 1988 to 2001 for 6 provinces. The share of individuals employed in the state and collective sectors falls from 93 percent in 1995 to 81 percent in 2001. In Figure 1, we present a more detailed breakdown for 2003 using the entire national urban household survey sample. 71 percent of workers are employed in the state and collective sectors, with 39.2 percent working in state-owned enterprises, 25.6 in government organizations, and 7.0 in collective enterprises. Overall, these numbers suggest much higher levels of state and collective sector employment and a slower rate of decline in such employment than the statistics reported in Tables 1 and 2.

\footnotetext{
${ }^{3}$ Although the China Labor Statistical Yearbook does not provide a source for these numbers, they are likely to come from the CLSRS because breakdowns are provided by sector and official employment data by sector is from the CLSRS.
} 
Of course, the main reason for the discrepancy between the structure of ownership calculated from urban household survey data and other sources is that the urban household survey excludes nearly all migrants from its sample. ${ }^{4}$ However, this alone is insufficient to explain away the differences. Even if we assume that migrants comprise 20 percent of urban employment, no migrants work in the state or collective sector, and the NBS urban household survey is a representative sample of urban permanent residents, this would imply that 56 percent of urban laborers worked in the state and collective sectors in 2003, much higher than the 31 percent reported in Table 1 based on the numbers reported by the CLSRS. A 2002 Ministry of Labor survey of 75,000 households in 66 cities focused on urban permanent residents also found that 60 percent of workers were employed in the state or collective sectors.

Part of the difference could be that the NBS urban household survey is not fully representative due to refusal bias. For example, highly mobile workers who change jobs frequently may be less likely to stay in the NBS survey sample, which requires that selfrecorded diaries be kept year-round. In a much larger urban household survey conducted by NBS in 2004 using a brief survey instrument, information on 340,000 employed workers was obtained, of which 57 percent worked in the state or collective sectors, which is considerably lower than the 71 percent calculated using the 2003 urban household survey. ${ }^{5}$ Adjusting for the lack of data on migrants as before produces a revised estimate that at least 46 percent of urban workers are employed in the state or collective sectors.

\footnotetext{
${ }^{4}$ Since 2003, migrants have been included in the urban household survey sample, but migrants account for less than 1.5 percent of the sample, which is much below the 17 percent of the urban non-agricultural labor force reported in Table 2. ${ }^{5}$ The NBS 2004 short form survey sample, like the NBS urban household survey sample in the same year, included very few migrants (less than $4 \%$ of sampled workers).
} 
One way of reconciling the remaining gap between the survey-based and unit reporting-based estimates of the share of the urban labor force in the state and collective sectors is to allow for the possibility that the state and collective sectors hire urban permanent residents informally and do not register them as employees when reporting to the CLSRS. This explanation accords well with field interviews that found that many laid off workers were hired by government agencies or state-owned enterprises in a highly informal way, with no labor contract, part-time hours, wages paid per hour worked, and no social insurance provided. To avoid the payroll charges for social insurance programs, many enterprises would have a natural incentive to hire as many workers as possible on an informal basis.

How common is this type of informal employment of urban permanent residents? Cai and Wu (2006) examine this question by analyzing survey data collected by the Ministry of Labor in 66 cities nationwide at the end of $2002 .{ }^{6}$ The survey collected data on over 75,000 households and 189,000 individuals older than 16 years of age. The MOL 66-city survey asked detailed questions about employers, whether there was a labor contract, work conditions, and social insurance coverage. The survey concentrated nearly exclusively on urban permanent residents. The authors applied multiple criteria to determine if an individual worker was employed informally. The most important categories are those who are self-employed workers, those who work on a temporary or hourly basis, and those who lack a labor contract and are not considered officially

\footnotetext{
${ }^{6}$ The MOLSS surveyed 13 large cities above 2 million population, 8 cities with population between 1 and 2 million, 10 cities with population between 500 thousand and 1 million population, 19 cities with population between 200 and 500 thousand, and 16 cities with population less than 200,000. The number of households surveyed in each size group was $3000,2500,2000,1500$, and 800, with 20 households surveyed in a given neighborhood.
} 
registered workers. $^{7}$ A rich description of the extent of informal employment among different subgroups of the population is provided in Table 5, taken from Cai and $\mathrm{Wu}$ (2006). The authors find that 45 percent of employment is informal in nature. In the state and collective sectors, 22 percent of employment is informal, while in other sectors informal employment is the rule rather than the exception, accounting for 84 percent of workers. Informal employment also is more prevalent among women, among the youngest and oldest workers, and among less educated workers (Table 5).

If we assume that state and collective sector employees reported to the CLSRS are all employed formally (31 percent of all urban labor in 2003) and that 22 percent of total state and collective sector employment is informal (which excludes informally employed migrants), then the share of all urban workers employed in the state and collective sectors would be 40 percent. We have now made considerable progress in reconciling the different estimates of state and collective sector employment from different sources. These calculations also imply that workers employed informally in the state and collective sectors account for 9 percent of the urban labor force.

In Table 6, we provide further evidence on the extent of formal and informal employment among different types of employers, drawing upon survey data from the China Urban Labor Survey conducted in five large and five smaller cities in different regions of China. ${ }^{8}$ An advantage of the CULS data is that it also surveyed migrants in the same cities. A weakness of the survey is that it under-samples workers living in

\footnotetext{
${ }^{7}$ The following types of workers were categorized as informal: 1) hired workers without formal contract not listed as formal employees; 2) domestic workers, temporary agency workers, and casual laborers; 3) community service workers without formal contract; 4) workers hired on the basis of hourly pay, daily pay, weekly pay, and uncertain pay (in terms of time and/or account); 5) paid helpers in family and self-employed businesses; 6) workers hired by individual entrepreneurs (getihu); 7) individual business owners (getihu), note that the ILO recommends that small business of less than 10 workers be considered informal, in China individual businesses are those with 7 or fewer workers. Workers in the agricultural sector are excluded in the analysis.

${ }^{8}$ The five large cities are Shanghai, Fuzhou, Xian, Wuhan, and Shenyang and the five small cities located in the same regions are Wuxi, Zhuhai, Baoji, Yichan, and Benxi.
} 
dormitories or worksites, so that it over-represents self-employed workers. We report the share of workers with formal labor contracts, broken down by type of employer. Lacking a labor contract is of course only one indicator of informal employment, and it is even possible that some permanent workers will not recall signing an official document and so report not having a labor contract even though they are permanently employed. We find that 62 percent of urban permanent residents have labor contracts while only 13 percent of migrants have labor contracts. As expected, the share of those with labor contracts is highest in the government and state sectors. It is very low in the private sector, with 27 percent of urban permanent residents and only 7 percent of migrants having labor contracts. Across all ownership categories, the share of workers with labor contracts is lower for migrants than for urban permanent residents. However, because over 85 percent of migrants are in the private sector, where the prevalence of labor contracts is lowest, the rate of informal employment among all migrants is extremely high. This also suggests that missing migrants and missing private sector workers are likely to have a large overlap.

\section{The service sector}

In January 2006, China’s NBS announced revised GDP estimates based on the results of the economic census undertaken in 2005. The main adjustment was a significant increase by nearly 50 percent in the 2004 GDP of the tertiary, or services, sector. Adjustments for previous years were made back to 1994. As seen in Figure 3, as a result of the revisions, the share of the tertiary sector in overall GDP increased from 
31.9 to 40.7 percent while the shares of the primary and secondary sectors decreased from 15.2 and 52.9 percent to 13.1 and 46.2 percent.

The changes reflect new discovery of previously unrecorded economic activity reported by work units, but they don’t necessarily imply similar adjustments are required for the number of workers in the tertiary sector since the employment data are based on the labor force surveys which in principle cover the entire population. Assuming that the adjusted tertiary sector GDP is accurate, then in 200433 percent of tertiary sector activity was not recorded under the previous statistical system (Table 7). If the output to labor ratio of recorded and unrecorded activity is roughly the same, then the same percentage of employees (33 percent) in the tertiary sector were engaged in activity not recorded by the CLSRS. That implies that 76 million workers were involved in tertiary sector activity in 2004 without the output being recorded, or 19 percent of all those employed in the secondary and tertiary sectors (Table 7). Although these calculations don't distinguish between activity in rural areas, if most secondary and tertiary activity is in urban areas, it does provide an indication of how many "missing' workers may have been engaged in undocumented tertiary sector activity.

\section{2008 Labor Contract Law}

China passed a landmark Labor Law in 1994, formalizing for the first time the system of labor contracting (Cai, Du, and Wang, 2009). Since then, other incremental reforms have been passed. But none of these was as important as the new Labour Contract Law which came into effect on January 1, 2008. The new law reaffirms the requirement that all workers sign formal contracts and participate in social insurance 
programs, strengthens rights to collective bargaining, requires severance payments be paid when contracts are not renewed, and, most controversially, requires that workers with 10 consecutive years of service, or having signed two consecutive fixed-term contracts with a company, be given a contract without a fixed end date. Many employers have complained that the new law will raise labour costs and limit employment flexibility. In recent years, China also has implemented other reforms affecting the treatment of labor, including a comprehensive document to protect the rights of migrant workers (2006), new rules to improve labor dispute resolution, and new social insurance programs to make migrants benefits more portable and to extend health insurance and pension coverage to the self-employed and non-employed.

Enforcement of the new Law could have a large impact on the prevalence of informal employment but because the change is so recent, there is little empirical evidence on the Law's actual impact. In principle, the Law's emphasis on formal labor contracts should increase the share of workers formally employed, but also could lead firms to be more cautious in hiring workers when it will be more costly and difficult than before to fire them. Interviews by the authors of labor bureau officials and enterprise managers in 2009 in Shenyang and Shanghai confirm that the Labor Law is being enforced, and that some workers have filed complaints and lawsuits to protect their rights under the new Law. However, the impact of the global financial crisis since late 2008 could have weakened enforcement of the Law if local governments helped firms cope with the crisis by reducing enforcement of labor regulations.

Surveys directed by the authors of about 400 urban residents in two Chinese cities, Shenyang in the northeast and Shenzhen across the border from Hong Kong, provide some 
evidence on the enforcement of the new Labor Law. ${ }^{9}$ Results of the survey are summarized in Table 11. Despite the new Law, a surprisingly low percentage of local workers signed labor contracts in Shenyang (34\%), and even fewer migrants (19\%). In Shenzhen, a much higher percentage of both local workers and migrants signed contracts (61\% and 67\%, respectively). Again the evidence suggests that migrants are treated similarly as local residents in Shenzhen, but not in Shenyang. Migrant workers in both cities who do sign contracts are more likely to sign fixed-term contracts than local residents. Respondents are mostly satisfied with how well employers are abiding by the new Labor Law, but with different levels of enthusiasm. Very few respondents are highly critical (rank employers as "very poor”). Migrants have a somewhat more negative assessment than local residents. The survey also finds no evidence that adherence to the Labor Law has been undermined by the onset of the economic crisis, with assessments of compliance changing little between August 2008 and March 2009, the time of the survey. Overall, the results yield some optimism that the new Law is being taken seriously despite the economic downturn.

\section{Discussion}

Drawing upon multiple data sources, we have documented a rapid, unprecedented rise in informal employment in urban China since the mid-1990s. By 2005, 10 percent of urban workers were registered as self-employed, and another 36 percent were undocumented, neither reported by employers nor self-registered. We have shown that

\footnotetext{
${ }^{9}$ In each city, 100 households were surveyed, 10 households in each of 10 neighborhoods which were selected to be regionally representative of each city. In half of the neighborhoods local residents were randomly sampled and in the other half migrants were randomly sampled, yielding a sample of 50 local resident households and 50 migrant households in each city. Information was collected for all adults living each of the sample households, yielding a sample of about 400 individuals, with slightly more local residents than migrants (220 versus 180).
} 
many of these "missing" workers were likely to be employed in the private sector and in the service sector. Most migrant workers are employed informally, but a large number of urban permanent residents are also employed informally.

Is informalization of the Chinese labor market a positive or negative development? On the positive side, the informal sector creates jobs and allocates labor based on market principles, thus furthering the development of the labor market. On the negative side, informalization creates new policy challenges because the government is poorly informed about informal economic activities and has difficulty regulating such activity. This makes it hard to enforce protective regulations for workers that ensure safe working environments and fair treatment of workers. It also makes it difficult to develop sustainable social insurance systems that cover most of the population and which are adequately financed. Table 8 shows that informal workers have very low rates of social insurance coverage compared to formal workers. According to the MOLSS 66-city survey in 2002, the share of informal workers with pension, unemployment, and health insurance were 37, 21, and 14 percent compared to 85, 73, and 62 percent for formal workers. Migrants are particularly vulnerable. According to the CULS in 2005, the share of migrants with pension, unemployment, and health insurance was 11,5 , and 11 percent (Table 9). Even urban residents had highly incomplete coverage, with 77, 39, and 68 percent enjoying pension, unemployment, and health insurance. For all of these reasons, the informalization of the Chinese labor market is exposing urban workers to considerably more uncertainty and risk, creating new vulnerability in the lives of China's urban citizens. 


\section{References}

Cai, Fang, and Yaowu Wu. 2006. China's urban informal employment: scale and characteristics, mimeo.

Gallagher, Mary. 2009. “China’s Older Workers: Between Law and Policy, Between Laid-Off and Unemployed,” in Thomas B. Gold, Qiang Li, William J. Hurst, and Jaeyoun Won, eds., Laid-Off Workers in a Workers' State: Unemployment with Chinese Characteristics (Palgrave Macmillan).

Maitra, Pushkar, Ingrid Nielsen, Chris Nyland, Russell Smyth, and Cherrie Zhu (2005). Firm compliance with social insurance obligations where there is a weak surveillance and enforcement mechanism: empirical evidence from Shanghai, mimeo, Monash University. 
Figure 1

Employment by ownership type, 1978 to 2005

(China Statistical Yearbook, various years)

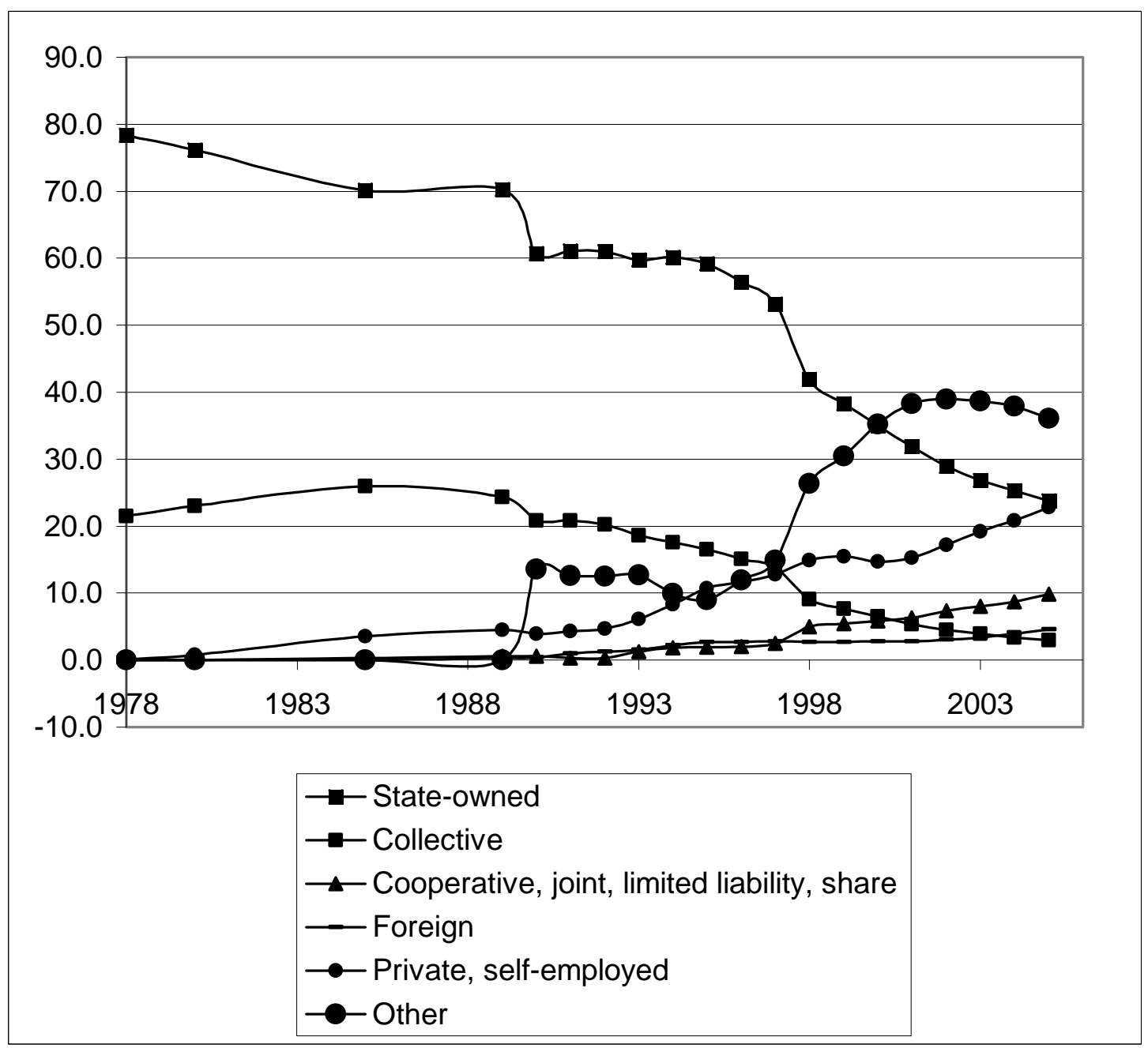


Figure 2

Employer ownership types, NBS 2003 urban household survey

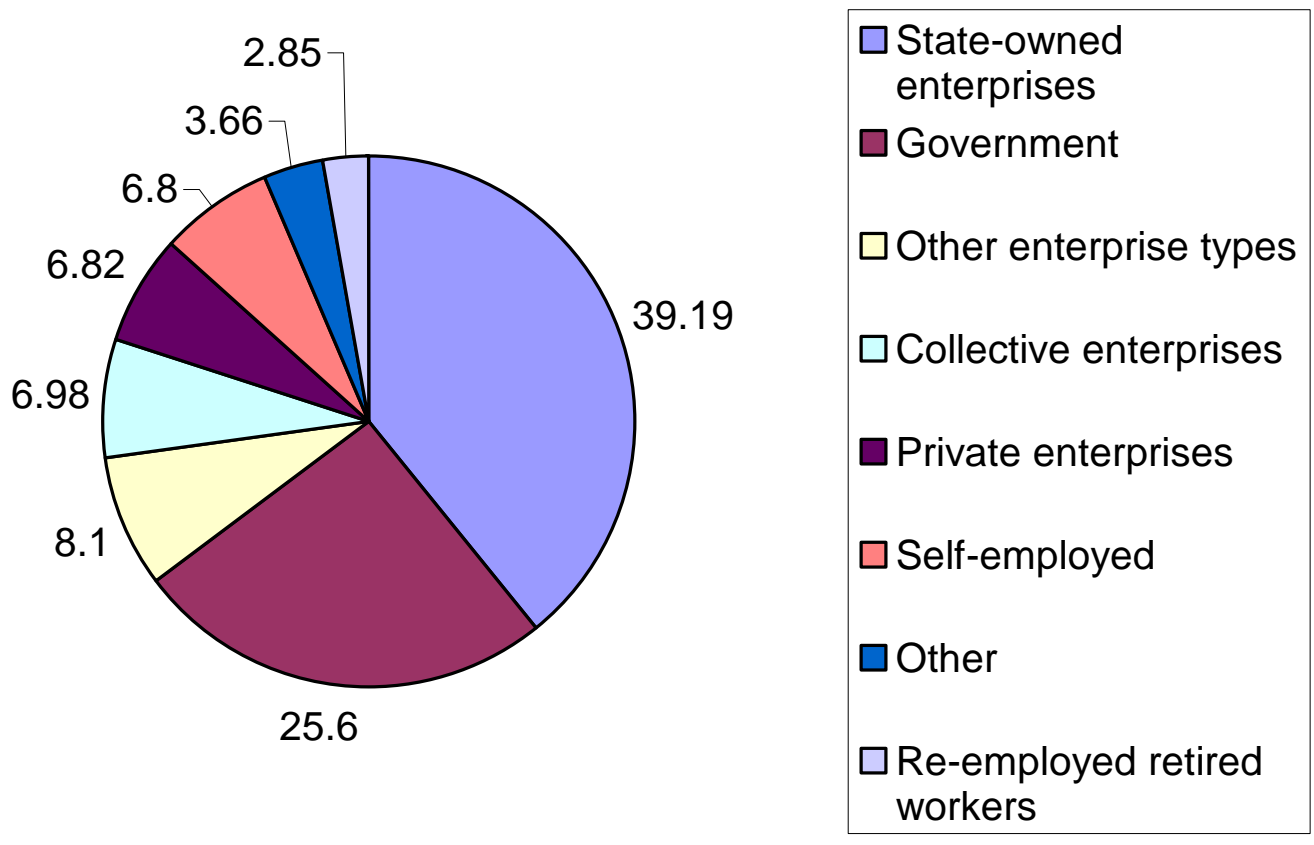


Figure 3

Revised GDP statistics, January 2006

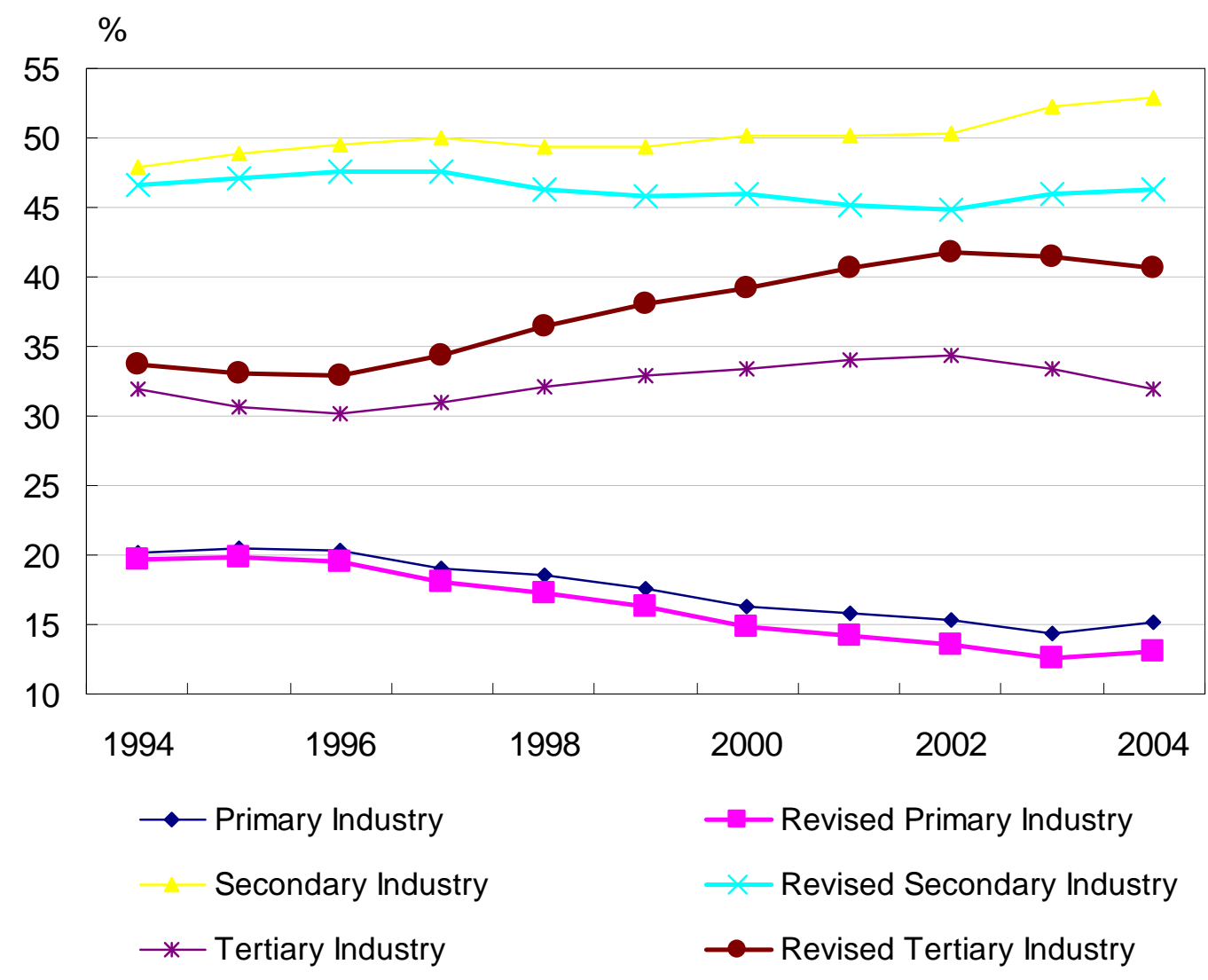


Table 1

Urban Employment Shares by Ownership Type, 1978-2005

\begin{tabular}{|c|c|c|c|c|c|c|c|c|c|c|}
\hline Year & State-owned & Collective & Cooperative & $\begin{array}{c}\text { Joint } \\
\text { Ownership }\end{array}$ & $\begin{array}{c}\text { Limited } \\
\text { Liability } \\
\text { Corporations }\end{array}$ & $\begin{array}{c}\text { Share } \\
\text { Holding } \\
\text { Corporations }\end{array}$ & $\begin{array}{c}\text { Private } \\
\text { Enterprises }\end{array}$ & $\begin{array}{c}\text { Foreign and } \\
\text { Joint } \\
\text { Ventures }\end{array}$ & $\begin{array}{c}\text { Self- } \\
\text { employed }\end{array}$ & Other \\
\hline 1978 & 0.78 & 0.22 & 0.00 & 0.00 & 0.00 & 0.00 & 0.00 & 0.00 & 0.00 & 0.00 \\
\hline 1980 & 0.76 & 0.23 & 0.00 & 0.00 & 0.00 & 0.00 & 0.00 & 0.00 & 0.01 & 0.00 \\
\hline 1985 & 0.70 & 0.26 & 0.00 & 0.00 & 0.00 & 0.00 & 0.00 & 0.00 & 0.04 & 0.00 \\
\hline 1989 & 0.70 & 0.24 & 0.00 & 0.01 & 0.00 & 0.00 & 0.00 & 0.00 & 0.05 & 0.00 \\
\hline 1990 & 0.61 & 0.21 & 0.00 & 0.01 & 0.00 & 0.00 & 0.00 & 0.00 & 0.04 & 0.14 \\
\hline 1991 & 0.61 & 0.21 & 0.00 & 0.00 & 0.00 & 0.00 & 0.00 & 0.01 & 0.04 & 0.13 \\
\hline 1992 & 0.61 & 0.20 & 0.00 & 0.00 & 0.00 & 0.00 & 0.01 & 0.01 & 0.04 & 0.13 \\
\hline 1993 & 0.60 & 0.19 & 0.00 & 0.00 & 0.00 & 0.01 & 0.01 & 0.02 & 0.05 & 0.13 \\
\hline 1994 & 0.60 & 0.18 & 0.00 & 0.00 & 0.00 & 0.02 & 0.02 & 0.02 & 0.07 & 0.10 \\
\hline 1995 & 0.59 & 0.17 & 0.00 & 0.00 & 0.00 & 0.02 & 0.03 & 0.03 & 0.08 & 0.09 \\
\hline 1996 & 0.56 & 0.15 & 0.00 & 0.00 & 0.00 & 0.02 & 0.03 & 0.03 & 0.09 & 0.12 \\
\hline 1997 & 0.53 & 0.14 & 0.00 & 0.00 & 0.00 & 0.02 & 0.04 & 0.03 & 0.09 & 0.15 \\
\hline 1998 & 0.42 & 0.09 & 0.01 & 0.00 & 0.02 & 0.02 & 0.05 & 0.03 & 0.10 & 0.26 \\
\hline 1999 & 0.38 & 0.08 & 0.01 & 0.00 & 0.03 & 0.02 & 0.05 & 0.03 & 0.11 & 0.31 \\
\hline 2000 & 0.35 & 0.06 & 0.01 & 0.00 & 0.03 & 0.02 & 0.05 & 0.03 & 0.09 & 0.35 \\
\hline 2001 & 0.32 & 0.05 & 0.01 & 0.00 & 0.04 & 0.02 & 0.06 & 0.03 & 0.09 & 0.38 \\
\hline 2002 & 0.29 & 0.05 & 0.01 & 0.00 & 0.04 & 0.02 & 0.08 & 0.03 & 0.09 & 0.39 \\
\hline 2003 & 0.27 & 0.04 & 0.01 & 0.00 & 0.05 & 0.02 & 0.10 & 0.03 & 0.09 & 0.39 \\
\hline 2004 & 0.25 & 0.03 & 0.01 & 0.00 & 0.05 & 0.02 & 0.11 & 0.04 & 0.10 & 0.38 \\
\hline 2005 & 0.24 & 0.03 & 0.01 & 0.00 & 0.06 & 0.03 & 0.13 & 0.05 & 0.10 & 0.36 \\
\hline
\end{tabular}


Table 2

Employment Comparison: 2000 CLSRS and Census by Sector (thousand persons, \%)

\begin{tabular}{lcccccc}
\hline & CLSRS & Census & \% Missing & Urban & R-U & \% of \\
& Total & Total & Workers & Residents & Migrants & Migrants \\
\hline Total & 144594 & 171734 & 18.8 & 118660 & 29319 & 17.1 \\
Mining and Quarrying & 5975 & 4060 & -32.0 & 3416 & 316 & 7.8 \\
Manufacturing & 39334 & 56739 & 44.2 & 36745 & 13774 & 24.3 \\
$\begin{array}{l}\text { Electricity, Gas and } \\
\text { Water }\end{array}$ & 2838 & 3398 & 19.7 & 2610 & 153 & 4.5 \\
Construction & 8598 & 10680 & 24.2 & 6777 & 2674 & 25.0 \\
$\begin{array}{l}\text { Geological Prospecting } \\
\text { Transport and }\end{array}$ & 1102 & 695 & -36.9 & 553 & 32 & 4.6 \\
$\begin{array}{l}\text { Telecomm. } \\
\text { Trade \& Catering }\end{array}$ & 8588 & 12220 & 42.3 & 9506 & 1096 & 9.0 \\
Services & 29338 & 35271 & 20.2 & 23561 & 7091 & 20.1 \\
Finance and Insurance & 3268 & 3450 & 5.6 & 2389 & 147 & 4.3 \\
$\begin{array}{l}\text { Real Estate Trade } \\
\text { Social Services }\end{array}$ & 1004 & 1533 & 52.7 & 1014 & 143 & 9.3 \\
$\begin{array}{l}\text { Health and Social } \\
\text { Welfare }\end{array}$ & 9220 & 11680 & 26.7 & 7653 & 2132 & 18.3 \\
Educ, Culture and & 4881 & 5530 & 13.3 & 4201 & 311 & 5.6 \\
$\begin{array}{l}\text { Broadcast } \\
\text { Science and Polytech }\end{array}$ & 15658 & 11189 & -28.5 & 8446 & 719 & 6.4 \\
Services & & & & & & \\
Gov’t \& Social & 1745 & 1379 & -21.0 & 1025 & 35 & 2.5 \\
$\begin{array}{l}\text { Organizations } \\
\text { Others }\end{array}$ & 11038 & 12483 & 13.1 & 9676 & 587 & 4.7 \\
\hline
\end{tabular}

Note: 1. In the census data, employment denotes those who are 15 years old and above. 2. Employment in agricultural sector is not included.

Source: NBS and MOLSS, China Labor Statistical Yearbook 2001; 0.95\% Sampling Data of $5^{\text {th }}$ National Census Long Form 


\section{Table 3}

Urban employment by employer type from labor force surveys, 2001 to 2004

\begin{tabular}{lcccccccc}
\hline Year & $\begin{array}{c}\text { Urban } \\
\text { units }\end{array}$ & TVEs & $\begin{array}{c}\text { Agricultu } \\
\text { re }\end{array}$ & & \multicolumn{2}{c}{$\begin{array}{c}\text { Private } \\
\text { sector } \\
\text { employe }\end{array}$} & $\begin{array}{c}\text { Private } \\
\text { employer }\end{array}$ employe \\
(geti) & d & Others & Total \\
\hline 2001 & 49.2 & 3.7 & 12.6 & 12.0 & 6.1 & 13.6 & 2.8 & 100.0 \\
2002 & 44.1 & 3.7 & 17.2 & 14.1 & 6.2 & 12.8 & 1.8 & 100.0 \\
2003 & 44.0 & 3.8 & 15.0 & 15.5 & 6.5 & 13.3 & 2.0 & 100.0 \\
2004 & 40.2 & 3.7 & 14.0 & 18.8 & 7.1 & 13.4 & 2.9 & 100.0 \\
\hline
\end{tabular}

Source: NBS annual population and labor force surveys, Labor Statistical Yearbooks, various years. Agriculture excluded.

Table 4

Ownership type of workers employers from NBS urban households in 6 provinces, 1988-2001

\begin{tabular}{ccccc}
\hline Year & $\mathrm{N}$ & $\begin{array}{c}\text { State-owned unit } \\
(\%)\end{array}$ & $\begin{array}{c}\text { Urban collective } \\
(\%)\end{array}$ & $\begin{array}{c}\text { Non-public } \\
\text { enterprises (\%) }\end{array}$ \\
\hline 1988 & 6,087 & 74.5 & 24.8 & 0.7 \\
1989 & 5,615 & 75.2 & 23.8 & 1.0 \\
1990 & 6,194 & 76.0 & 22.9 & 1.1 \\
1991 & 6,225 & 77.2 & 21.8 & 1.1 \\
1992 & 7,853 & 76.5 & 20.7 & 2.8 \\
1993 & 7,017 & 76.1 & 20.4 & 3.5 \\
1994 & 6,752 & 76.8 & 17.8 & 5.4 \\
1995 & 6,830 & 78.0 & 15.4 & 6.6 \\
1996 & 6,651 & 78.5 & 15.2 & 6.4 \\
1997 & 6,641 & 77.4 & 14.9 & 7.7 \\
1998 & 6,331 & 76.8 & 14.4 & 8.8 \\
1999 & 6,094 & 74.0 & 14.0 & 12.0 \\
2000 & 6,197 & 72.6 & 11.3 & 16.1 \\
2001 & 5,404 & 70.2 & 10.9 & 19.0 \\
\hline
\end{tabular}

Provinces: Beijing, Liaoning, Zhejiang, Guangdong, Shaanxi, Sichuan 
Table 5

Share of informal and formal employment in urban China in $\mathbf{2 0 0 2}$ (percent)

\begin{tabular}{lcc}
\hline & Informal Employment & Formal Employment \\
\hline All & 45.25 & 54.75 \\
By sector: & 22.87 & 77.13 \\
$\quad$ State and collective & 83.99 & 16.01 \\
New & & \\
By sex: & 42.16 & 57.84 \\
Male & 49.52 & 50.48 \\
Female & & \\
By age: & 57.24 & 42.77 \\
16-24 & 44.57 & 55.44 \\
$25-34$ & 42.23 & 57.77 \\
35-44 & 42.17 & 57.83 \\
$45-54$ & 55.63 & 44.37 \\
55-64 & 83.88 & 16.12 \\
>65 & & \\
By education level: & 78.41 & 21.6 \\
Primary and below & 62.59 & 37.41 \\
Middle school & 48.63 & 51.37 \\
High school & 35.85 & 64.15 \\
Junior technical school & 24.55 & 75.45 \\
Specialized college & 14.75 & 85.25 \\
College and above & & \\
\hline
\end{tabular}

Source: Cai and Wu (2006), calculated from Ministry of Labor 66-city survey. 
Table 6

Share of workers with formal labor contracts

(China Urban Labor Survey 2005)

\begin{tabular}{|c|c|c|c|c|}
\hline & \multicolumn{2}{|c|}{ Urban permanent residents } & \multicolumn{2}{|c|}{ Migrants } \\
\hline & $\begin{array}{c}\text { Has labor } \\
\text { contract } \\
(\%) \\
\end{array}$ & $\begin{array}{c}\text { Employment } \\
\text { share } \\
(\%)\end{array}$ & $\begin{array}{c}\text { Has labor } \\
\text { contract } \\
(\%)\end{array}$ & $\begin{array}{c}\text { Employment } \\
\text { share } \\
(\%)\end{array}$ \\
\hline All & 61.8 & & 12.9 & \\
\hline Government & 76.2 & 0.236 & 43.2 & 0.030 \\
\hline State-owned & 88.5 & 0.306 & 55.6 & 0.032 \\
\hline Collective & 71.7 & 0.052 & 47.4 & 0.016 \\
\hline Private & 26.5 & 0.281 & 7.0 & 0.847 \\
\hline Foreign and joint ventures & 74.9 & 0.057 & 57.8 & 0.023 \\
\hline Other & 28.4 & 0.068 & 18.0 & 0.054 \\
\hline
\end{tabular}

Note: City samples for 10 large and 10 small cities given equal weight.

Table 7

Employment Implications of China's 2006 GDP revisions

\begin{tabular}{|c|c|c|c|c|c|c|}
\hline & $\begin{array}{c}\text { Unrevised } \\
\text { tertiary sector t } \\
\text { GDP } \\
\text { (billion yuan) }\end{array}$ & $\begin{array}{l}\text { Revised } \\
\text { ertiary sector } \\
\text { GDP }^{1} \\
\text { billion yuan) }\end{array}$ & $\begin{array}{l}\text { "Missing" share } \\
\text { of tertiary GDP }\end{array}$ & $\begin{array}{l}\text { Secondary } \\
\text { sector } \\
\text { employ- } \\
\text { ment } \\
\text { (millions) }\end{array}$ & $\begin{array}{l}\text { Tertiary } \\
\text { sector } \\
\text { employ- } \\
\text { ment } \\
\text { (millions) }\end{array}$ & $\begin{array}{c}\text { Imputed } \\
\text { "missing" share } \\
\text { of secondary and } \\
\text { tertiary sector } \\
\text { employment }\end{array}$ \\
\hline & $(1)$ & $(2)$ & $\begin{array}{c}(3) \\
=[(2)-(1)] /(2)\end{array}$ & (4) & (5) & $\begin{array}{c}(6) \\
=(3) *(5) /[(4)+(5)]\end{array}$ \\
\hline 1996 & 2043 & 2346 & 0.13 & 162 & 179 & 0.07 \\
\hline 1997 & 2303 & 2717 & 0.15 & 165 & 184 & 0.08 \\
\hline 1998 & 2517 & 3078 & 0.18 & 166 & 189 & 0.10 \\
\hline 1999 & 2704 & 3410 & 0.21 & 164 & 192 & 0.11 \\
\hline 2000 & 2990 & 3894 & 0.23 & 162 & 198 & 0.13 \\
\hline 2001 & 3315 & 4463 & 0.26 & 163 & 202 & 0.14 \\
\hline 2002 & 3607 & 5020 & 0.28 & 158 & 211 & 0.16 \\
\hline 2003 & 3919 & 5632 & 0.30 & 161 & 218 & 0.18 \\
\hline 2004 & 4372 & 6502 & 0.33 & 169 & 230 & 0.19 \\
\hline
\end{tabular}

${ }^{1}$ Revised January 2006 
Table 8

Social insurance coverage under informal and formal employment, Ministry of Labor 66-city Survey 2002

\begin{tabular}{lcc}
\hline & $\begin{array}{c}\text { Informal workers } \\
(\%)\end{array}$ & $\begin{array}{c}\text { Formal workers } \\
(\%)\end{array}$ \\
\hline Pensions & 37.0 & 84.5 \\
Unemployment & 20.7 & 72.5 \\
Health & 14.1 & 61.5 \\
\hline
\end{tabular}

Table 9

Urban Informal Employment Shares in 2005 (\%)

\begin{tabular}{lcccc}
\hline & Local residents & Rural migrants & $\begin{array}{c}\text { Urban } \\
\text { migrants }\end{array}$ & All \\
\hline Cities & 43.7 & 68.1 & 35.8 & 48.2 \\
Townships & 60.4 & 70.8 & 50.1 & 61.6 \\
All urban & 50.1 & 68.8 & 38.1 & 52.6 \\
\hline
\end{tabular}

Source: IPLE Project Group (2007), analyzing 2005 1\% mini-census data. Informal employment includes self-employed, those without formal contracts.

Table 10

China social insurance coverage rates by location type and formality of employment, 2005 population mini-census

\begin{tabular}{lccc}
\hline & Pensions & Health Insurance & Unemployment \\
\hline All & 17.9 & 32.9 & 13.6 \\
By location type: & & & \\
$\quad$ Cities & 42.4 & 47.1 & 23.1 \\
$\quad$ Towns & 19.7 & 32.8 & 10.2 \\
$\quad$ Rural & 3.9 & 25.3 & 2.7 \\
By employment formality & & & \\
(urban): & & & \\
$\quad$ Formal employment & 73.8 & 78.0 & 54.7 \\
$\quad$ Hired & 26.6 & 30.5 & 10.2 \\
$\quad$ Employer & & & \\
$\quad$ Informal employment & 19.5 & 26.6 & 7.9 \\
$\quad$ Hired & 11.8 & 21.2 & 2.6 \\
$\quad$ Self-employed & 11.5 & 19.9 & 2.4 \\
$\quad$ Household labor & & & \\
\hline
\end{tabular}

Source: IPLE Project Group (2007), analyzing 2005 1\% mini-census data. Informal employment includes self-employed, those without formal contracts. 
Table 11

Compliance with the 2008 Labor Contract Law

\begin{tabular}{|c|c|c|c|c|}
\hline & \multicolumn{2}{|c|}{ Local residents } & \multicolumn{2}{|c|}{ Migrants } \\
\hline & Shenyang & Shenzhen & Shenyang & Shenzhen \\
\hline \multicolumn{5}{|c|}{ Have you signed labor contract with your working unit or employer for your current job? } \\
\hline Yes & 34.3 & 60.9 & 18.8 & 66.7 \\
\hline No & 53.4 & 14.1 & 40.6 & 21.7 \\
\hline Self employment & 12.3 & 25.0 & 40.6 & 11.6 \\
\hline \multicolumn{5}{|c|}{ Before August of 2008, how well did your employer abide by the labor contract law? } \\
\hline Very well & 46.8 & 13.0 & 42.4 & 26.6 \\
\hline Satisfactory & 40.3 & 68.8 & 36.4 & 31.7 \\
\hline Just so so & 10.4 & 16.9 & 19.7 & 35.4 \\
\hline Very poorly & 2.6 & 1.3 & 1.5 & 6.3 \\
\hline \multicolumn{5}{|c|}{ Currently, how well does your enterprise abide by the labor contract law? } \\
\hline Very well & 47.5 & 8.2 & 46.9 & 26.7 \\
\hline Satisfactory & 34.4 & 69.9 & 37.5 & 30.7 \\
\hline Just so so & 14.8 & 20.6 & 15.6 & 37.3 \\
\hline Very poorly & 3.3 & 1.4 & 0.0 & 5.3 \\
\hline
\end{tabular}

Based on surveys of a random sample of 50 local residents and 50 migrant households in each city, conducted by the Institute of Population and Labor Economics (CASS) in March 2009. 